\title{
Marcin CHRUŚCIEL
}

V Liceum Ogólnokształcące im. Augusta Witkowskiego w Krakowie

44chrust@gmail.com

\section{PROCESUALNOŚĆ POSTPAMIĘCI I JEJ REPREZENTACJE W LITERATURZE ORAZ SZTUCE WSPÓŁCZESNEJ}

ABSTRACT Postmemory's Processuality and Its Representations in Literature and Contemporary Art

The text is an attempt to analyze literary postmemory representation in three scenes confronted with the language of art. The subject matter are novels: Zagtada (Extinction) by Piotr Szewc, Tworki by Marek Bieńczyk and Pensjonat (Pension) by Piotr Paziński and an exhibition: Poland - Israel - Germany. Auschwitz Experience at the Museum of Contemporary Art MOCAK in Krakow. These books had their premieres at intervals of at least ten years, becoming marks of consecutive decades of duration of the concept of postmemory. Zagtada (1987), Tworki (1999) and Pensjonat (2009) could be read as another mainstream views of the postmemory and building a horizon of contemporary Polish literature. In dialogue with these novels an exhibition open on the $15^{\text {th }}$ of May, 2015 in MOCAK has been submitted to analysis. The intention of the text is to point transformations in postmemory in different fields of artistic activity.

Keywords: contemporary art, Polish novel, postmodernism, Holocaust

Słowa kluczowe: sztuka współczesna, powieść polska, postmodernizm, Holokaust 
Trudno rozpocząć wypowiedź na temat wydarzenia, jakim był Holokaust, oraz sposobów jego upamiętniania bez wielu zwyczajowych zastrzeżeń. Rozstrzygnięcie dylematu wyrażonego przez Theodora W. Adorno ${ }^{1}$ wydaje się jednoznaczne $z$ uwagi na ogromną liczbę dzieł traktujących o losie Żydów podczas II wojny światowej. Jednak olbrzymia produkcja literacka czy, szerzej, artystyczna oraz nie mniejsza biblioteka rozpraw teoretycznych nie zamykają sprawy. Powstawanie kolejnych dzieł nie zmienia faktu, że trudno komuś odmówić prawa do uznania ich za niestosowne. Emocje i sprzeczne opinie wywoływane przez utwory zajmujące się najogólniej pojmowanym doświadczeniem Holokaustu dobitnie świadczą o żywotności tematu. Skomplikowaną sytuację doskonale wyraził cytowany przez Michała Głowińskiego Azriel Rosenfeld: Holokaust domaga się stów, nawet jeśli zmusza do milczenia ${ }^{2}$. Z uwagi na ograniczoną objętość niniejszego tekstu właściwy temat zostanie zawężony do jednego zagadnienia. Konieczne jest przy tym wskazanie, w jakich okolicznościach powstały dzieła, które zostaną tutaj omówione.

Mamy zatem literaturę teoretycznego namysłu, zawierającą opis strategii radzenia sobie z kłopotliwym tematem. Wśród wspomnianych strategii wymieniane są kategorie stosowności, uniwersalizacji czy neutralizowania ${ }^{3}$. Warto pamiętać, że polska literatura czy, szerzej, polski dyskurs o Zagładzie w PRL-u były przedmiotem polityki historycznej państwa. Trudno było oczywiście ówczesnym decydentom uniknąć konfrontacji ze sprawami oczywistymi, jak chociażby konieczność czy dziejowy obowiązek upamiętnienia ofiar Auschwitz i stworzenia instytucji muzeum. Jednak już budowana przez władzę wokół muzeum narracja wyrażała chęć ukształtowania świadomości społecznej w taki sposób, by utrwalić Auschwitz jako miejsce obozu koncentracyjnego i zagłady obywateli wieloetnicznej przedwojennej Rzeczpospolitej.

Zatem temat Zagłady z uwagi na wiele czynników (majątki pożydowskie to tylko jeden z nich) i wydarzeń polskiej polityki powojennej był pomijany milczeniem lub - co gorsza - zakłamywany. Dość powiedzieć, że tekst Jana Błońskiego Biedni Polacy patrza na getto (uznawany za przełomowy, wyznaczający nową jakość w polskiej dyskusji nad

1 Adorno w dziele Prismen. Kulturkritik und Gesellschaft (1951) wyraził tezę: Pisanie wierszy po Oświęcimiu jest barbarzyństwem. Interesujące omówienie dylematu, przed jakim stanęła literatura powojenna, prezentuje w swoim artykule A.A. Zych, Liryka nieludzkiego świata Auschwitz, „Krytyka Literacka” 2014, nr 2/4, s. 1-6, [online] http://krytykaliteracka.blogspot.com/2014/11/papierowa-krytyka-literacka-nr-24.html, http://wielekmandrela.republika.pl/teksty/krytyka.pdf, 13.11.2015.

2 Stosowność i forma. Jak opowiadać o Zagtadzie?, red. M. Głowiński i in., Kraków 2005, s. 12.

3 Por. D. Krawczyńska, Wstęp, [w:] Literatura polska wobec Zagtady (1939-1968), red. S. Buryła, D. Krawczyńska, J. Leociak, Warszawa 2012, s. 9-22. Warto także zwrócić uwagę na następujące pozycje: Literatura wobec wojny i okupacji. Studia, red. M. Głowiński, J. Sławiński, Wrocław 1976, Z Dziejów Form Artystycznych w Literaturze Polskiej, 43; Reprezentacje Holokaustu, wybór i oprac. J. Jarniewicz, M. Szuster, Kraków-Warszawa 2014; B. Krupa, Opowiedzieć Zagtadę. Polska proza i historiografia wobec Holocaustu (1987-2003), Kraków 2013; Pamięć Shoah. Kulturowe reprezentacje i praktyki upamiętniania, red. T. Majewski, A. Zeidler-Janiszewska, współpr. red. M. Wójcik, Łódź 2011. 
Zagładą) opublikowano dopiero w 1987 r. Zarówno ten tekst, jak i wcześniejszy o dwa lata film Claude’a Lanzmanna Shoah spotkały się z niesłychanie żywym, by nie powiedzieć: niekiedy agresywnym odzewem ${ }^{4}$. Po 1989 r. budowanie świadomości Polaków wyznaczają spory o „krzyż papieski” na oświęcimskim żwirowisku oraz debata o zbrodni w Jedwabnem i o zajmującej się tym tematem książce Sąsiedzi Jana Tomasza Gros$\mathrm{sa}^{5}$. Temperatura i zasięg dyskusji wywołanej publikacją Grossa wskazywały niezbicie, że zbiorowe zapominanie Zagłady, jakie zafundowali sobie (oczywiście niekoniecznie dobrowolnie) Polacy w czasach PRL-u, doprowadziło do zmagazynowania traumy w zbiorowej podświadomości ${ }^{6}$. Joanna Tokarska-Bakir w tekście z 2003 r., zatytułowanym Polska jako chory cztowiek Europy ${ }^{7}$, b bliskiej perspektywy komentuje dyskusję o Jedwabnem, zwracając uwagę, że krajowi historycy zmarnowali szansę rzeczywistego (a co za tym idzie - ostatecznego) przepracowania traumy. Tokarska-Bakir komentuje również definicję postpamięci zaproponowaną przez Marianne Hirsch (mowa w niej o przenoszeniu traumy z ocalałych uczestników Zagłady na kolejne pokolenia, na dzieci i rodziny, które dorastały i kształtowały się w cieniu Holokaustu). Polska eseistka zwraca uwagę na rozwój kultury posttraumatycznej w końcówce lat 80 . XX w.

Podstawę konstrukcji niniejszego artykułu stanowi przeświadczenie o sensowności porównawczego zestawienia trzech powieści. Zagtada (1987) Piotra Szewca, Tworki (1999) Marka Bieńczyka i Pensjonat (2009) Piotra Pazińskiego zostały wydane mniej więcej w dziesięcioletnich odstępach, co pozwala potraktować te trzy różne dzieła jako kolejne punkty jednego procesu, nazwanego na potrzeby niniejszego artykułu procesualnością postpamięci. Zakładam, że próby literackiego wyrażenia postpamięci w perspektywie 30-letniego wycinka czasu uwidaczniają dwa niezbywalne składniki tego procesu: temporalność oraz nawarstwienie doświadczeń rozumiane jako poszerzenie zbioru środków wyrazu. Proces zakłada ciągłość (tak pożądaną z perspektywy ofiar Holokaustu) oraz unikanie powtarzania pomysłów z przeszłości, ciągłe poszukiwanie nowych odczytań opartych na rozwiązaniach autorów wcześniejszych narracji.

Zakres materiału badawczego obejmuje dzieła prozatorskie współczesnej literatury polskiej publikowane w okresie zaledwie 30 lat oraz prace Artura Żmijewskiego, Agaty Siwek, Mirosława Bałki i Wilhelma Sasnala prezentowane na krakowskiej wystawie Polska - Izrael - Niemcy. Doświadczenie Auschwitz dzisiaj (MOCAK, 2015). Wybór materiału badawczego pozwoli udowodnić tezę, że temat Zagłady - pozostając dla literatury i sztuki zagadnieniem ciągle ważnym i nieopracowanym - wymusza konieczność poszukiwań oryginalnego języka, nowego sposobu wypowiedzi. Postpamięć oznacza

\footnotetext{
Podsumowanie wspomnianej debaty wokół wystąpienia Błońskiego można odnaleźć w „Tygodniku Powszechnym” (Lektor, Ciężar pamięci, „Tygodnik Powszechny” 1995, nr 4, s. 13) oraz w tekście Głowińskiego Jan Btoński „Biedni Polacy patrzą na getto” w 20 lat później, „Zagłada Żydów. Studia i materiały" 2005 , nr 1.

5 J.T. Gross, Sąsiedzi. Historia zagtady żydowskiego miasteczka, Sejny 2000.

6 Relację z dyskusji o książce J.T. Grossa Sąsiedzi znaleźć można w: P. Forecki, Od „Shoah” do „Strachu”. Spory o polsko-żydowska przesztość i pamięć w debatach publicznych, Poznań 2010.

J. Tokarska-Bakir, Polska jako chory cztowiek Europy? Jedwabne, „postpamięć” i historycy, „Eurozine” 2003, 30 V, [online] http://www.eurozine.com/articles/2003-05-30-tokarska-pl.html, 15 X 2015.
} 
zatem trwanie Holokaustu w świadomości kolejnych powojennych pokoleń, a drugi składnik frazy, tj. procesualność, wskazuje na niejednorodność i zmienność sposobów przedstawienia Szoa w sztuce.

Warto w tym miejscu wspomnieć o koncepcji aktu narracyjnego rozumianego jako anamnesis (przypominanie): Po 1945 roku [...] doszto do wstydliwego porzucenia, wyparcia polsko-żydowskiej koegzystencji, zaś traume [...] inkorporowano do nowej spotecznej, powojennej tożsamości, zbudowanej na niepamiętaniu przesztości. Trauma ta zostata odziedziczona przez pokolenia urodzone w PRL-u, które w drugiej potowie lat osiemdziesiatych będą chciaty ja wyrazić poprzez odprawienie nostalgicznej żatoby - narracyjnego wskrzeszenia tego, co byto, $w$ celu zaleczenia rany. $Z$ tego punktu widzenia anamnesis to pamięć przedbytowa, odziedziczona po sttumionej przesztości [...] $]^{8}$. Literatura ma za zadanie budować tożsamość zbiorowości poprzez odpominanie wydarzeń, które zostały usunięte z dyskursu publicznego. Pisarze, będący reprezentantami wspomnianych powyżej pokoleń urodzonych w PRL-u, odczuwając napięcie wywołane wyparciem doświadczeń wojennych, rozwiązania szukają w ponownym przywołaniu duchów przeszłości.

\section{II}

Jednym ze sposobów radzenia sobie z tematem Holokaustu jest wykorzystanie kategorii wzniosłości, którą zastosował w książce Zagtada Piotr Szewc. Wzniosłość uzyskał przez obrazowanie nostalgiczne oraz mitologizację elementów świata przedstawionego. Jesteśmy oto - czytelnicy książki - wędrowcami po niewielkim miasteczku (może Zamościu) przedwojennym. Mamy nieograniczoną wiedzę i możliwości poznania skrytych motywów zachowań bohaterów, nawet ich myśli. Narrator książki swój wyimaginowany małomiasteczkowy świat, przechowywany przez wrażliwą pamięć, opiera na doświadczeniu oglądania fotografii. Szewc tworzy zarys postaci narratora - człowieka zamkniętego w sobie, enigmatycznego - z którym spacerujemy ulicami miasteczka, krążąc wokół centralnej Listopadowej. Narrator opisuje, jak kolejnymi przyciśnięciami palca produkuje zapis odchodzącego w niebyt świata. Dostarcza szczegółowych, pełnych pietyzmu opisów przedmiotów, wnętrz oraz ludzkich zachowań, często rutynowych, powtarzalnych, niekiedy o mocy rytuału.

Celebrowanie świata oparto na precyzyjnym opisie postępowania kilkorga bohaterów podczas jednego tylko dnia. Ten dzień jest cenny i istotny właśnie ze względu na swoją powszedniość - jest bowiem ukazaniem żywiołu egzystencji. Życie ludzkie zdaje się poddawać kontemplacji w promieniach podwójnego słońca (drugim jest kopuła wieży ratusza, królującej nad miastem): Wszystko jest przed nami, wszystko jest wokót nas. Przychodzi powtórzyć prawde oczywista i ciagle ważna: jesteśmy w Centrum. Jesteśmy na Poczattku i Końcu. Jesteśmy w miejscu rozchodzenia się czterech kierunków dróg. Można nimi opuścić Centrum, nimi do Centrum się wraca. Ruch po kole ${ }^{9}$. Nostalgicz-

$8 \quad$ B. Krupa, Opowiedzieć Zagtadę..., s. 68-69.

9 P. Szewc, Zagtada, Kraków 2003, s. 55. 
na i mityczna stylizacja wyjścia bohatera do lasu, gdzie, poznając przyrodę, dostępuje wtajemniczenia w misterium życia i śmierci, żywo przypomina Dolinę Issy Czesława Miłosza. Jeden z bohaterów Szewca, mecenas Walenty Daniłowski, w nostalgicznych wspomnieniach przywołuje zamierzchłe wydarzenia, jak to młody Walek uratował przed kolegami gromadkę bezbronnych ptaszków. Czyżyki spłoszone uciekły, uciekł też Walek przed zemstą chłopców. Przywołanie wrażliwości dziecka pozwala oswoić niepokojące sny, jakie nawiedzają mecenasa, sny o biegających po mieście psach - diabłach rozświetlających wszystko ogniem i ścigających przerażonych ludzi.

Autor książki, wspominając okoliczności jej powstania, mówi o zimie stanu wojennego, kiedy jako student pierwszego roku polonistyki zaczął pisać, by przetrwać, by uciec od grozy rzeczywistości. Twórczość zyskuje zatem moc terapeutyczną, jednak do obrazowania jednego letniego dnia (od świtu do zmierzchu) w przedwojennym miasteczku powraca Szewc jeszcze dwukrotnie. Te powroty wyznaczają kolejne książki autora: Zmierzchy i poranki (2000) oraz Bociany nad powiatem (2005). Okazuje się zatem, że pisarz odnalazł sposób na udźwignięcie ciężaru tematu: opowiedzieć o Zagładzie, rezygnując z dosłownego opisu, ufając wrażliwości i wiedzy czytelnika. Unikamy potworności Holokaustu, jednak jest on jednym z podstawowych skojarzeń, kiedy czytamy opis idylliczności świata lat 30. Warto przywołać słowa Ingi Iwasiów, która wspomina, że Piotr Szewc odnalazł najlepszy sposób na opisanie Holokaustu. Nie tylko nie użyt tego stowa, nie zarysowat najmniejszej możliwości jego ekspozycji. Przedstawit świat nabrzmiaty od życia, erotycznie spetniony, wyczekujacy na ciag dalszy ${ }^{10}$.

Zresztą sam wędrujący ulicami miasteczka narrator nie unika przedstawiania swojego credo: Być czujnym. Rejestrować pilnie, by niczego w Księdze nie zabrakto. Co trudne do naocznego stwierdzenia, powotywać do rzeczywistości prawem prawdopodobieństwa. [...] Esencja zdarzeń, rzeczy. Odwieczna, z mroków nieprzebytych wywiedziona metafizyka. [...] Widzieć. Być. Zapamiętywać. Utrwalać skrupulatnie. Jeszcze jedna fotografia. Ijeszcze jedna. Podązać za uciekajacym. Nie przegapić ${ }^{11}$.

\section{III}

Tworki Marka Bieńczyka wydano w 1999 r. i od tego czasu powieść ta doczekała się wielu komentarzy, stając się niezbywalnym elementem każdej większej pracy podsumowującej literaturę, która podejmuje temat Holokaustu. Akcja książki rozgrywa się w dwu planach czasowych: mamy narratora z czasów współczesnych, który przesiaduje na ławce w szpitalu psychiatrycznym Tworki pod Warszawą, oraz siedzących na ławce w tym samym miejscu pracowników szpitala z czasów niemieckiej okupacji lat II wojny światowej.

Młody warszawiak Jurek jest zakochany w Sonii, która swe serce odda Olkowi, przystojnemu piłkarzowi Polonii. W jednym pokoju z Jurkiem pracuje Marcel Brochowicz,

\footnotetext{
10 Cyt. za: B. Krupa, Opowiedzieć Zagtadę..., s. 118.

11 P. Szewc, Zagtada..., s. 76-83.
} 
a jego żona Anna mieszka poza Tworkami. Ostatecznie partnerką Jurka zostanie Janka, ostatnia w kręgu przyjaciól. Do świata przedstawionego w powieści dołącza jeszcze adresatka listów Jurka - Danka, niebiorąca bezpośrednio udziału w wydarzeniach. Budowa zależności pomiędzy bohaterami pozwala mówić o realizacji figury romantycznej: niespełnionej miłości. Pierwsza część książki (do uroczystych imienin Sonii) odwołuje się do narracji bukolicznej; sam narrator przywołuje Laurę i Filona jako wyznaczniki tonacji. Druga część przywodzi na myśl powieść o dojrzewaniu. Postaci budowane są na zasadzie kontrastu: jeśli Jurek jest młodym poetą w okularach, Olek musi być dziarskim sportowcem, któremu składanie dłuższych wypowiedzi przychodzi niezgrabnie. Ta oczywistość i widoczność elementów, z których sporządzono świat powieści, jest przykładem autotematyzmu dzieła, stosowania deziluzji charakterystycznej dla literatury postmodernistycznej. Mieszanina stylów i rejestrów języka, pokazanie żywiołu mowy jako wielkiego mechanizmu, który raz uruchomiony musi pracować, mimo potknięć i zgrzytów - te wskazówki wprawnie odczytywali recenzenci powieści Bieńczyka, konstatując, że najważniejsze rzeczy w Tworkach dzieją się w języku.

Temat Zagłady jest w książce przywołany w sposób nieoczywisty, tak jak narracja unika dosłowności i za naczelną cechę obiera nieoczywistość właśnie. Prawie wszyscy przyjaciele Jurka - Sonia, Danka, Marcel z Anną - znikają w niewyjaśnionych okolicznościach, pozostawiając enigmatyczne listy pożegnalne. Janka zaś przyznaje Jurkowi, że jest z Berdyczowa - tak bowiem określa się pochodzenie żydowskie (samo słowo Żyd ani razu nie pojawia się w powieści). Berdyczów (od powiedzenia „pisać na Berdyczów", czyli na nieistniejący adres) oznacza miejsce nieistniejące, wyrwę w świecie, nicość, w której rozpłynęli się Żydzi. Zagadka zniknięcia Sonii jest w istocie zagadką anihilacji Żydów.

Czytelnik zaczyna łączyć w całość rozsiane w powieści sygnały: pacjenci szpitala spacerują w pasiastych piżamach, w tle widzimy dymiące kominy, a szpitalne baraki oznaczone są symbolami przywodzącymi na myśl obóz w Auschwitz. Na domiar złego podopiecznymi lekarzy są Rubens, Vivaldi, Antyplaton, jakby imiona-pseudonimy Tworkowskich wariatów miały sugerować, że cała cywilizacja europejska znalazła się w domu obłąkanych, świat oszalał.

Jest w powieści scena, która pokazuje niebezpieczeństwo kryzysu. To rozmowa Antyplatona z Jurkiem, będącym na skraju załamania nerwowego i odmawiającym uczestniczenia w dialogu, w którym miałby opowiedzieć o śmierci Sonii. Poczciwy Antyplaton zachęca Jurka, by ten, jak to miał w zwyczaju, ułożył wiersz, co mogłoby ułatwić sprawę. Jurek początkowo nie chce nawet wymówić słów „człowiek” czy „człowieczeństwo" i odmawia znalezienia rymu do imienia Sonia. Po chwili jednak wypowiada komiczną frazę: Sonia - trąbę i uszy ma stonia. Okazuje się, że język zwycięża; jest żywiołem o mocy wiecznego trwania. Powyższa scena nie jest - jak można by sądzić egzemplifikacją bankructwa języka (czego potwierdzeniem miałby być fakt wypowiedzenia przez Jurka zdania groteskowego, bezsensownego). W ostatecznej interpretacji przywołanej sceny ważniejsze jest, że bohater nie zamyka się w milczeniu, które znaczyłoby odmowę uczestnictwa w świecie. Mowa nakazuje mu wejście w kontakt z drugim człowiekiem, powrót do odgrywanej roli i definiujących go stosunków z otoczeniem. 
Jurek zaczyna od komicznej rymowanki, przypominającej dziecięce formy aktywności, którą równie dobrze można nazwać zaklęciem przywołującym magiczną moc języka.

Tworki Bieńczyka przypominają Zagtadę Szewca, ponieważ podobnie jak w powieści o dekadę wcześniejszej stosują zabieg mówienia o Zagładzie bez jej wspominania, bez nazywania samego zjawiska. Bieńczyk dokonał ważnej i niezwykle przenikliwej rzeczy: wpisując Holokaust w ramy powieści gatunkowej, wyraźnie pokazując nieprzystawalność tematyki Zagłady Żydów do konwencji romantycznej, szczególnie wyraziście uzmysławia czytelnikowi niewyrażalność, grozę, niepojętość samego Szoa. Paradoksalnie, poprzez zgrzytającą maszynę literacką buduje doświadczenie odbiorcy, fundowane na przekonaniu, że inaczej nie można, że oto odkryliśmy najlepszy może sposób powiedzenia prawdy o Zagładzie. Tylko w świadomości niedoskonałości narzędzi, ich braku i w zgodzie na niekompletność, ułomność świata przedstawionego utrwalimy jednostkowy wymiar straty. Żeby ostatni raz zacytować opracowanie Bartłomieja Krupy: [...] narracja Bieńczyka ma swoja stawkę - jest nia wyrażenie niewyrażalności Zagtady. Gra znaków pozbawionych znaczeń stuży tu oddaniu Holocaustu jako pustki i nieobecności ${ }^{12}$.

Kiedy Bieńczyk wychyla się zza struktury świata przedstawionego, kiedy pokazuje swoje ludzkie ograniczenia, jest szczególnie przejmujący. Marcel gtaszczący Anne po wtosach i catujacy jej oczy [...] zdania, mówione na melodię biaty domek: Twoje ciche stowa bardzo pięknie brzmia. Twoje usta pragna, a twe oczy l'snią. Rzecz jednakże w tym, moja żono, jest, że zamiast Szwajcarii czeka raczej piec13. Maty biaty domek to przedwojenny szlagier, warto jednak przypomnieć, że tę piosenkę śpiewa jeden z bohaterów filmu Lanzmanna Shoah w scenie otwierającej ten kilkugodzinny dokument. Marcel przeczuwa śmierć w pułapce, a jego strach i wierność żonie są tak niezwykle wiarygodne, ludzkie z dwu powodów. Po pierwsze - narrator staje się Bieńczykiem, który pisze: Ja już dalej nie pójdę, Wola to dobre dla mnie miejsce, więc widzę cię tylko od tytu. Plecy trzymasz prosto, idziesz wcią̇ powoli, walizeczka jeszcze dynda, ale stabiej. Zapomniatem, czy wtożyteś krawat, to teraz już nie zobaczę ${ }^{14}$. Zawiesza zatem wszechwiedzę twórcy, nie może skłonić bohatera, by się odwrócił, a tym bardziej nie ma możliwości, by być z nim do końca, towarzyszyć w odejściu z tego świata. Dlatego wzruszające okazują się słowa Bieńczyka, że chciałby namówić Marcela na ostatnie pokazanie czarującego uśmiechu, jeśliby tylko zechciał wrócić po pożegnalne upominki: butelkę whisky z czerwoną nalepką, bilet miesięczny na kolejkę i komputer z polską czcionką. Paczka na drogę złożona z rekwizytów codzienności, z przedmiotów współczesnych pisarzowi. Stąd w ostatnich zdaniach tego rozdziału powieści nie może być mowy o konwencjonalności literackich figur. Pisarz składa zapadający w pamięć hołd zamordowanym: Do Marcela Jerzego Brochowicza, do Marcela Jerzego Brochowicza palce moje i usta - chwata i cześs ${ }^{15}$.

\footnotetext{
B. Krupa, Opowiedzieć Zagtadę.., s. 333.

M. Bieńczyk, Tworki, Warszawa 1999, s. 124.

14 Tamże, s. 128.

15 Tamże, s. 129.
} 
Trzecia z przywołanych we wstępie książek to Pensjonat Piotra Pazińskiego z 2009 r. Justyna Sobolewska w recenzji powieści napisała, że oto mamy pierwszy w Polsce literacki głos trzeciego pokolenia po Holokauście. Bohater tego dzieła po latach wraca do pensjonatu Śródborowianka, położonego przy linii kolejowej Otwock-Warszawa, by obudzić duchy przeszłości. Paziński jako uczeń szkoły podstawowej na przełomie lat 70. i 80. był wożony do autentycznego pensjonatu w Śródborowie. Jak wspomina, pensjonat już przed wojną był jednym z wielu żydowskich ośrodków uzdrowiskowych na wspomnianej linii, zaś po wojnie przetrwał jako arka dla żydowskich dzieci; organizowano w nim kolonie, przez jakiś czas był tam także sierociniec. Pensjonat w książce Pazińskiego to miejsce, do którego narrator odbywa nostalgiczną podróż w przeszłość. Przybywa do ośrodka po dziesięcioleciach, wspominając czasy dorastania - jedzie ze świadomością, że zapamiętane osoby już nie żyją, a wnętrze pensjonatu zaludniają duchy.

Tożsamość byłych mieszkańców pensjonatu była żydowska i ślady pamięci o Żydach trwają we wspomnieniach snutych w starych murach. W Śródborowiance ci, którzy nie wyjechali z Polski w 1968 r., czują się u siebie, chociaż przecież wyznawcy Jahwe nigdy nie są u siebie, zawsze w drodze, jak na tylnej ptaskorzeźbie na pomniku bohaterów getta, gdzie rabin $z$ Tora prowadzi lud ${ }^{16}$. Pamiątki z przeszłości to pożółkłe, rozpadające się gazety, skrawki - bohater zdaje się sugerować, że pamięć znika wraz z ostatnimi żyjącymi świadkami wydarzeń. Niezależnie od elegijnych tonów i konstrukcji niemal onirycznego nastroju, podniosły styl jest równoważony sygnałami pogodzenia się z losem. Żydzi są w Polsce od zawsze i zawsze będą, bo ich ślady są nieusuwalne. Słyszymy też głosy sugerujące konieczność akceptacji losu: Czego on chce? Co się raz stato, już się nie odstanie. Ile można drzećszaty? Cate życie, a nawet dtużej? Ubrania nie wystarczy ${ }^{17}$. W innym miejscu powieści padają słowa Abrama, który stracił w czasie wojny całą rodzinę, ale pozostat w Polsce, bo ktośmusi pilnować kości $i^{18}$.

Wspomniany pan Abram dziełem swojego życia czyni spisywany słownik biograficzny wszystkich Żydów, którzy kiedyś mieszkali w Polsce. Słownik zapisywany na skrawkach papieru, zużytych kopertach, kwitach z pralni i biletach tramwajowych. Życiorysy przerwane w połowie jak bilety właśnie.

Kolejna scena to spojrzenie na zdjęcie z dawnego, zmiecionego przez wojnę świata. Widzimy na fotografii twarze ludzi, którzy odeszli w niebyt i których losów nigdy nie poznamy. Utwór Pazińskiego jest jednolity w tonacji, zdaje się jednak wysyłać sprzeczne sygnały odnośnie do trwałości pamięci o Zagładzie. Z jednej strony pogodzenie z przemijaniem, akceptacja stanu rzeczy, odejścia świadków zbrodni, a z drugiej - zapowiedzi trwania pamięci przez pokolenia. Jednak tej sugerowanej sprzeczności wcale nie

\footnotetext{
16 P. Paziński, Pensjonat, Warszawa 2009, s. 20.

17 Tamze, s. 31-32.

18 Tami̇e, s. 41.
} 
ma. Narrator Pensjonatu tłumaczy, że nie pamięta już większości wydarzeń ze swojego dzieciństwa; może do nich wrócić jedynie dzięki pamiątkom: A więc tutaj kiedyśspacerowatem. Mam fotografię, jak siedzę okrakiem na powyginanej sośnie. Powinna być gdzieś w pobliżu. Ot, kilka kroków. Siedzę na niej, w zagięciu pnia, w jesiennym paletku i czapce kominiarce, chociaż jest gorace lato. Teraz, jesienia, kilka lat później, nie znajdę już tego drzewa - co drugie jest tu powyginane, nie rozpoznam gtosów tamtego lasu. Zdaje mi się, $\dot{z}$ e wszystko, co tutaj robie, to archeologia pamięci zapadtej w mroku, jak te drzewa i jak resztki drewnianych domów ${ }^{19}$.

W rozmowie z Pawłem Duninem-Wąsowiczem Piotr Paziński przyznał, że w świecie powieści Pensjonat bardzo mało jest życia religijnego, bo pozostali w Polsce Żydzi, z którymi się stykał, to byli świeccy ludzie, zostawiający religię za sobą ${ }^{20}$. Zarazem mówi o tym, że religia jest ważnym składnikiem tożsamości, staje się inspiracją do działania. Wokół religii, wokół pytań o naturę Boga i świata toczyli dysputy panowie Abram i Leon w obecności małego bohatera - co w oczywisty sposób przywołuje skojarzenia z kłótniami Naphty i Settembriniego z Czarodziejskiej góry. Zatem tożsamość Żydów oparta na religii i przymierzu z Bogiem jako na czymś wyjątkowym nie czyni ich jednocześnie niezwykłymi. Spory ze Stwórcą są odwieczne dla rodzaju ludzkiego; w historii Izraelitów pytania są może stawiane w bardziej dramatyczny sposób.

Paziński w Pensjonacie pokazuje, jak w jednostkowej świadomości, w kruchej i nietrwałej pamięci, nakładają się na siebie dwa plany historii narodu żydowskiego: wyjście z Egiptu występuje w paraleli z pozostaniem w okupacyjnej Warszawie. Skoro bohater zapomina swoje dzieciństwo i może do niego dotrzeć jedynie poprzez odpominanie, odczytywanie śladów zapisanych w niszczejących pamiątkach, to dopuszczalne, bo jedyne możliwe, jest budowanie pamięci o losach minionych pokoleń również w oparciu o wietrzejące ślady historii. Książka napisana z perspektywy wnuka uczestniczki Holokaustu przynosi zgodę na ten stan rzeczy, na zrywanie ciągłości dotykalnej, weryfikowalnej poprzez obecność osób z numerami na przedramieniu i jednocześnie, poprzez ową akceptację, wyraża szacunek dla Zagłady. Mechanizm pozwalający na trwanie jednych i zacieranie się innych aspektów Szoa wynika z samej konstrukcji ludzkiej pamięci. Fakt oddalania się w czasie i wymierania świadków nie musi być zagrożeniem fundamentalnym. Niewiele więcej pamiętam. Chwilami tyle co nic. Moja przesztość tkwi we mnie gtęboko, lecz kiedy staram się do niej dotrzeć, natrafiam na wydrażona pustkę, jakbym urodzit sie wczoraj, a wszystko, co dawniej się wydarzyto, byto tylko gaszczem cienistych obrazów, zetlatych i rozsypanych $w$ drobiny atomów [...]. Nattok tych obrazów stwarza iluzję pamięci i podobnie jak mnogość fotografii staje się namiastka życia ${ }^{21}$.

\footnotetext{
19 Tamże, s. 73.
}

20 P. Paziński, Niedoszty syjonista, rozm. P. Dunin-Wąsowicz, 31.07.2009, [online] http://www.sztetl. org.pl/he/article/otwock/16,-/11402,niedoszly-syjonista-piotr-pazinski-rozmawia-z-redaktorem-pawlem-dunin-wasowiczem/, 5.11.2015.

21 Tenże, Pensjonat, s. 103. 
Mamy zatem do czynienia z sytuacją, kiedy artyści (np. pisarze), podejmując temat Zagłady w czasach o dziesięciolecia oddalonych od zdarzenia, kreślą mapę postpamięci społeczeństwa, rodziny narodowej. Różne rejestry wypowiedzi konkretnych twórców są wynikiem dojrzewania w innych okolicznościach, co widać na przykładzie utworów Piotra Szewca, Marka Bieńczyka oraz Piotra Pazińskiego. Po skrótowym opisaniu ich książek, układających się w sekwencję, serię rządzącą się logiką procesu historycznoliterackiego, można zadać pytanie: czy postpamięć wyrażana jest tylko w literaturze?

Na zakończenie warto zwrócić się ku szeroko pojmowanym sztukom plastycznym, co pozwoli nam dostrzec wieloznaczeniowość frazy „procesualność postpamięci”.

W Muzeum Sztuki Współczesnej w Krakowie (MOCAK) zorganizowano wystawę Polska - Izrael - Niemcy. Doświadczenie Auschwitz dzisiaj. Wedle jej kuratora, Delfiny Jałowik, jednym z podstawowych pytań, jakie dziś stawiają sobie artyści zajmujący się fenomenem Auschwitz, jest: czy najtragiczniejszy symbol, jaki stworzyła ludzka cywilizacja (obóz koncentracyjny w Auschwitz), po śmierci ostatnich bezpośrednich świadków stanie sie jedynie pustym i mrocznym motywem popkultury, czysta prowokacja, disneylandem horroru, czy takie obawy sa jednak przesadzone?22

Widoczne są trzy główne strategie twórcze, które stosowali autorzy prac zawartych na ekspozycji w MOCAK. Pierwsza z nich to prowokacja, rozumiana jako działania niezgodne z estetycznymi przyzwyczajeniami większości odbiorców. Praca Artura Żmijewskiego Berek z 1999 r. stała się na tyle głośna i wzbudziła tak wiele kontrowersji, że nie ma potrzeby streszczania jej wyglądu i założeń. Żmijewski w odczuciu wielu ludzi naruszył tabu, krzyżując zabawę w berka z wnętrzami komory gazowej. Przekazywanie roli berka utożsamione $\mathrm{z}$ wymierzeniem wyroku, skazaniem na śmierć, przed którą każdy próbuje uciec - takie interpretujące wyjaśnienie nie osłabia wcale drażliwości towarzyszącej oglądaniu filmu. Artysta uzmysławia odbiorcy, że Auschwitz obrosło w pewien zespół modelowych formuł upamiętniania przeszłości. Zza tego sztafażu nie przeziera już prawda, miejsce pamięci przestaje być dojmującą raną na ciele społeczeństwa.

Kolejnym krokiem po oswojeniu traumy Auschwitz jest wchłonięcie miejsca wraz z jego historią przez popkulturę i przemysł turystyczny. Tego dotyczą prace Mirosława Bałki oraz Agaty Siwek. Bałka w rzeźbie-tunelu z otworami układającymi się w napis AUSCHWITZWIELICZKA (2009) pokazuje niebezpieczeństwa włączenia Auschwitz w obieg kultury konsumpcyjnej, wpisanie na listę atrakcji, miejsc turystycznej eskapady. Natomiast Sitek wykonała naturalnych rozmiarów sklep/stoisko z pamiątkami: praca nosi tytuł Oryginalne pamiątki z Auschwitz-Birkenau (2002). Pamiątki opatrzone są metkami i cenami, w prowokacyjny sposób umieszczają elementy graficzne - symbole obozu lub nawiązania do ubrań więźniów - na płóciennych torbach na zakupy, tak popularnych obecnie przestrzeniach reklamowych.

22 D. Jałowik, Polska - Izrael - Niemcy. Doświadczenie Auschwitz dzisiaj, Kraków 2015, s. 9. 
Trzeci sposób namysłu nad problemem postpamięci jest praca Wilhelma Sasnala Maus 1 (2001) i Maus 2 (2015). W 2001 r. Sansal wykorzystał do swoich obrazów rysunki z komiksu Maus Arta Spiegelmana. Sam komiks wykorzystuje środki charakterystyczne dla popkultury, Sasnal natomiast usunął z obrazów postaci wraz z dymkami wypowiedzi, pozostawiając puste wnętrza: prycze, drzwi do komory gazowej. Artysta sugerował, jak mocno komiks Spiegelmana kształtuje wyobraźnię historyczną odbiorców i jednocześnie sugestywnie działał na emocje odbiorców, ukazując pustkę, nieobecność bohaterów. W 2015 r. Sasnal przemalował swoje obrazy w taki sposób, by usunąć jednoznaczność skojarzeń z wnętrzami obozu koncentracyjnego (np. na drzwiach domalował chiński znak równowagi z naturą). Jak wyjaśnia kurator wystawy: Przemalowując prace, które w obszarze historii sztuki sa sztandarowymi przedstawieniami, odwotującymi się do traumy obozu, Wilhelm Sasnal podkreślit zmiany w percepcji Auschwitz, a w konsekwencji również zmienność obrazów, symbolizujacych te wydarzenia ${ }^{23}$.

Procesualność odnosi się zatem również do zmian, jakie zachodzą w świadomości jednostki stającej przed wyzwaniem możliwie prawdziwego, unikającego schematów i powieleń przedstawienia trwania pamięci o Holokauście. Można wskazać proces, jakim jest przeobrażenie sposobów relacji o Zagładzie wynikające z próby ucieczki przed schematyzacją wypowiedzi, z pragnienia dotarcia do wrażliwości odbiorcy. Procesualność postpamięci można również rozumieć jako zanikanie jednych form pamiętania (relacje uczestników wydarzeń) i pojawianie się innych (narracje przedstawicieli drugiego i trzeciego pokolenia). Zatem każde kolejne pokolenie musi na nowo znaleźć odpowiedź na pytanie o współczesność Auschwitz, o to, czym ona jest dla konkretnej generacji. Niekiedy dotarcie do prawdy wyrażania w dziele sztuki odnoszącym się do Holokaustu pojawić się może dopiero, gdy twórca podda autotematycznej interpretacji indywidualny głos, jak uczynił to Sasnal.

$\mathrm{Na}$ prawach konkluzji chciałbym zaproponować sumaryczne zestawienie przypominające, że zarówno pisarze, jak i artyści współcześni nie chcą, nie mogą zignorować Holokaustu, który nadal stanowi niezwykle istotny temat. Znamienne jest, że stosowane są różne strategie, wypróbowywane liczne sposoby, by zasygnalizować problem najważniejszy dla każdego, kto pragnie opisać Zagładę: nieadekwatność dostępnych konwencji do „specyfiki” tematu. Pamięć Szoa w sztuce i literaturze to w istocie próby wyrażenia tematu niemożliwego do ogarnięcia. Opisane w niniejszym artykule, reprezentatywne dla wielu innych teksty i dzieła sztuki stanowią indywidualne próby zbudowania narracji oryginalnej, najtrafniej obrazującej paradoks wyzwania dokumentacji Holokaustu. Dodawanie kolejnych pomysłów do poszerzającego się zbioru rozwiązań buduje proces, przywoływany we wstępie tego tekstu. Procesualność odnosi się do historii literatury (sztuki), a także do dzieł poszczególnych prezentowanych autorów.

23 Tamże, s. 18. 


\section{BIBLIOGRAFIA}

Bieńczyk M., Tworki, Warszawa 1999.

Forecki P., Od „Shoah” do „Strachu”. Spory o polsko-żydowska przesztość i pamięć w debatach publicznych, Poznań 2010.

Jałowik D., Polska - Izrael - Niemcy. Doświadczenie Auschwitz dzisiaj, Kraków 2015.

Krawczyńska D., Wstep, [w:] Literatura polska wobec Zagtady (1939-1968), red. S. Buryła, D. Krawczyńska, J. Leociak, Warszawa 2012.

Krupa B., Opowiedzieć Zagtadę. Polska proza i historiografia wobec Holocaustu (1987-2003), Kraków 2013.

Literatura wobec wojny i okupacji. Studia, red. M. Głowiński, J. Sławiński, Wrocław 1976, Z Dziejów Form Artystycznych w Literaturze Polskiej, 43.

Pamięć Shoah. Kulturowe reprezentacje i praktyki upamiętniania, red. T. Majewski, A. Zeidler-Janiszewska, współpr. red. M. Wójcik, Łódź 2011.

Paziński P., Niedoszty syjonista, rozm. P. Dunin-Wąsowicz, 31.07.2009, [online] http://www. sztetl.org.pl/he/article/otwock/16,-/11402,niedoszly-syjonista-piotr-pazinski-rozmawia-z-redaktorem-pawlem-dunin-wasowiczem/.

Paziński P., Pensjonat, Warszawa 2009.

Reprezentacje Holokaustu, wybór i oprac. J. Jarniewicz, M. Szuster, Kraków-Warszawa 2014. Stosowność i forma. Jak opowiadać o Zagtadzie?, red. M. Głowiński i in., Kraków 2005.

Szewc P., Zagtada, Kraków 2003.

Tokarska-Bakir J., Polska jako chory cztowiek Europy? Jedwabne, „postpamięc" i historycy, „Eurozine" 2003, 30 V, [online] http://www.eurozine.com/articles/2003-05-30-tokarska-pl.html.

Dr Marcin CHRUŚCIEL, doktor literaturoznawstwa Wydziału Polonistyki Uniwersytetu Jagiellońskiego, nauczyciel polonista w V Liceum Ogólnokształcącym im. Augusta Witkowskiego w Krakowie. Współautor antologii Tekstylia bis. Stownik mtodej polskiej kultury (2006). Zainteresowania badawcze: antropologia literatury, literatura Holokaustu, performatyka i teatr współczesny. 